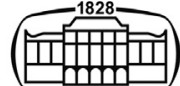

AKADÉMIAI KIADÓ

UNIVERSITY of DEBRECEN

\section{International Review of Applied Sciences and Engineering}

12 (2021) 1, 1-9

DOI:

$10.1556 / 1848.2020 .00064$

(c) 2020 The Author(s)

\title{
Tooth contact analysis of the effect of the addendum modification coefficient of helical gears having modified teeth
}

\author{
Sándor Bodzás* ๑ \\ Department of Mechanical Engineering, University of Debrecen, Ótemető str. 2-4., 4028 Debrecen, \\ Hungary
}

Received: October 24, 2019 • Accepted: January 17, 2020

Published online: December 15, 2020

\begin{abstract}
The helical gear pair is widely used in different mechanical constructions such as vehicle industry and working machine industry. The main property of them is the skew tooth direction with which better tooth connections could be available than in case of straight tooth direction. The analysis of the effect of the addendum modification coefficient for the normal stress and the normal deformation is the aim of the research which could be determined by finite element analysis. Five helical gear types are designed and modelled. The difference among them is only the different addendum modification coefficients. All of the other initial parameters are constant. After the result we determine the conclusions based on the diagram's results which are received by the mechanical parameters and the addendum modification coefficients.
\end{abstract}

\section{KEYWORDS}

helical gear, addendum modification, TCA, CAD, FEM, model, teeth

\section{INTRODUCTION}

According to the involute profile shape there are three helical gear types: $\mathrm{x}$-zero gear, normal teeth type and modified teeth type [1-4].

The geometric designing of many types of basic gear drives could be found in the [1-5] references. They are books where many designing questions are answered. They are essential for the designing. Based on these principles computer pieces of software were written for the easement of the designing and modelling process.

Many publications have been collected by great researchers which are related to this designing and connection analysis topic [6-19]. The researchers developed model for evaluating the load distribution of helical gears considering tooth modifications [6]. The dynamical analysis is also important in this field because of the stiffness analysis [7].

Due to the dynamic behaviour of these gears, they ended up revealing great potential in the reduction of noise, vibration and dynamic overload [7].

Accurate estimation of tooth-root stress has been of great interest to researchers and engineers to prevent catastrophic damage of gear transmission system [8].

The time-varying mesh stiffness (TVMS) of helical gears is obtained from the finite elements [9]. The efficiency is higher.

The stress analysis of the gears is important before the production. The established stresses could be followed and analysed by different loads [11].

Nowadays the additive technologies are worldwide because many products could be produced easily. This technology could be applicable in the gear production field [13].

The addendum modification is one of the most important parameters of the helical gears having modified teeth because it has effects for the profile shape, the addendums, the 
dedendums and the tip and root circle diameters. Consequently, the gear shape is modified but the gear connection is happening on the standard centre. The good selection of this component also influences the TCA results (especially stress and deformation) which would be proved in this study.

The $\mathrm{x}$-zero gear is the simplest where the standard centre distance is interpreted between the two gear axes and addendum modification coefficient is not used $(x=0)$ [4].

The normal centre distance $(a)$ is determined in the case of the helical gears having normal straight teeth. In this case the tooth connection is happening on the working pitch diameters [4]:

$$
d_{w 1,2}=\frac{d_{b 1,2}}{\cos \alpha_{g}}
$$

where:

- $\alpha_{g}$ - pressure angle $\left({ }^{\circ}\right)$.

- $d_{b 1,2}$ - basic circle diameters $(\mathrm{mm})$.

Determination of the $x_{1 h}$ addendum modification coefficient:

$$
x_{1 h}=\frac{\frac{d_{w 1}}{2}-h_{f 1}}{m}-\frac{z_{1}}{2}+\frac{h_{f 1}}{m}+c^{*}
$$

where:

- $h_{f 1}$ - dedendum of the pinion $(\mathrm{mm})$,

- $z_{1}-$ number of tooth of the pinion,

- $c^{*}$ - bottom clearance factor.

Based on these the $x_{2 h}$ addendum modification coefficient is [4]:

$$
x_{2 h}=\sum x_{h}-x_{1 h}
$$

where the sum of addendum modification coefficients [4]:

$$
\sum x_{h}=x_{1 h}+x_{2 h}=\frac{z_{1}+z_{2}}{2} \dot{s} \frac{i n v \alpha_{g}-i n v \alpha_{0}}{\operatorname{tg} \alpha_{0}}
$$

The tooth connection is happening on the pitch circle diameters that is why standard centre distance $\left(a_{0}\right)$ is used between the axis of rotations of the elements in the case of helical gears having modified straight teeth [1-5]. The sum of the two addendum modification coefficients is zero that is why they are inverse [4]:

$$
x_{1 h}+x_{2 h}=0 \rightarrow x_{1 h}=-x_{2 h}
$$

In this publication the helical gears having modified straight teeth are analysed based on the changing of the addendum modification coefficient.

Based on Fig. 1, five coordinate systems are necessary for the analysis of the gear pairs by mathematical way [2]:

- one coordinate system, $C_{P}\left(x_{P}, y_{P}, z_{P}\right)$, where the involute profile curve and the tooth surface could be determined,

- two standing coordinate systems of each element, $C_{1 S}\left(x_{1 S}\right.$, $\left.y_{1 S}, z_{1 S}\right), C_{2 S}\left(x_{2 S}, y_{2 S}, z_{2 S}\right)$,

- two rotation coordinate systems of each element, $C_{1 R}\left(x_{1 R}\right.$, $\left.y_{1 R}, z_{1 R}\right), C_{2 R}\left(x_{2 R}, y_{2 R}, z_{2 R}\right)$.

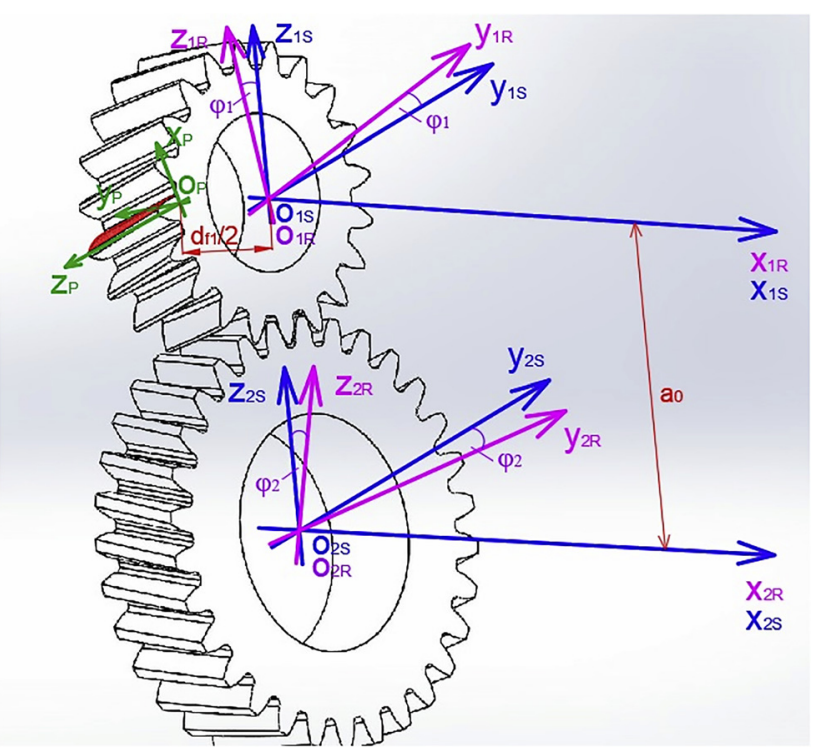

Fig. 1. The universal coordinate system's arrangement in the case of helical gears

Based on them the contact points of the elements could be determined and analysed by transformation matrixes and the Connection Statement I [2]:

$$
\vec{n}_{1 R} \dot{s} \vec{v}_{1 R}=\vec{n}_{2 R} \dot{s} \vec{v}_{2 R}=0
$$

\section{TOOTH CONTACT ANALYSIS}

\subsection{Designing and CAD modelling}

Based on the references' recommendations [1-19] we have created a computer software [20] with which the necessary geometric parameters could be determined (Table 1). This program can calculate the profile curves of the elements as well [20]. After that the CAD models could be built up by SolidWorks software (Fig. 2).

The axial module $(m)$ is interpreted on the standardized tool base profile. Tooth thickness $\left(S_{a x}\right)$ means a constant thickness on the pitch circles of the gears:

- the pitch on the face plane [4]:

$$
t_{o f}=\frac{m \dot{s} \pi}{\cos \beta_{0}}
$$

- the backlash [4]:

$$
j_{s}=\frac{t_{0}}{20}
$$

Based on (7) and (8) the tooth thickness is [4].

$$
S_{a x}=\frac{t_{o f}}{2}-\frac{j_{s}}{2}
$$

The shape of the profiles is modified because of the changing of the addendum modification coefficient. The tip thickness is continuously lower (Fig. 3). The pitch circle diameters and the standard centre distance are constant, but the other main diameters are changed (Table 1). 
Table 1. The determined parameters of the gear elements

\begin{tabular}{|c|c|c|c|c|c|}
\hline The main geometric parameters & Gear drive I. & Gear drive II. & Gear drive III. & Gear drive IV. & Gear drive V. \\
\hline Axial module $(\mathrm{m})[\mathrm{mm}]$ & & & 10 & & \\
\hline Number of tooth of the pinion $\left(z_{1}\right)$ & & & 20 & & \\
\hline Number of tooth of the driven gear $\left(z_{2}\right)$ & & & 30 & & \\
\hline Standard centre distance $\left(a_{0}\right)[\mathrm{mm}]$ & & & 258.919 & & \\
\hline Addendum of the pinion $\left(h_{a 1}\right)[\mathrm{mm}]$ & 10 & 11.035 & 12.070 & 13.105 & 14.141 \\
\hline Addendum of the driven gear $\left(h_{a 2}\right)[\mathrm{mm}]$ & 10 & 8.964 & 7.929 & 6.894 & 5.858 \\
\hline Bottom clearance $(c)[\mathrm{mm}]$ & & & 2.5 & & \\
\hline Dedendum of the pinion $\left(h_{f 1}\right)[\mathrm{mm}]$ & 12.5 & 11.464 & 10.429 & 9.394 & 8.358 \\
\hline Dedendum of the driven gear $\left(h_{f 2}\right)[\mathrm{mm}]$ & 12.5 & 13.535 & 14.570 & 15.605 & 16.641 \\
\hline Circular pitch $\left(t_{0}\right)[\mathrm{mm}]$ & & & 32.524 & & \\
\hline $\operatorname{Backlash}\left(j_{s}\right)[\mathrm{mm}]$ & & & 1.626 & & \\
\hline Whole depth $(h)[\mathrm{mm}]$ & & & 22.5 & & \\
\hline Working depth $\left(h_{w}\right)[\mathrm{mm}]$ & & & 20 & & \\
\hline Tooth thickness $\left(S_{a x}\right)[\mathrm{mm}]$ & & & 15.449 & & \\
\hline Pitch circle diameter of the pinion $\left(d_{1}\right)[\mathrm{mm}]$ & & & 207.055 & & \\
\hline Tip circle diameter of the pinion $\left(d_{a 1}\right)[\mathrm{mm}]$ & 227.055 & 229.125 & 231.196 & 233.266 & 235.337 \\
\hline Root circle diameter of the pinion $\left(d_{f 1}\right)[\mathrm{mm}]$ & 182.055 & 184.125 & 186.196 & 188.266 & 190.337 \\
\hline Basic circle diameter of the pinion $\left(d_{b 1}\right)[\mathrm{mm}]$ & & & 193.756 & & \\
\hline Pitch circle diameter of the driven gear $\left(d_{2}\right)[\mathrm{mm}]$ & & & 310.582 & & \\
\hline Tip circle diameter of the driven gear $\left(d_{a 2}\right)[\mathrm{mm}]$ & 330.582 & 328.512 & 326.441 & 324.371 & 322.300 \\
\hline Root circle diameter of the driven gear $\left(d_{f 2}\right)[\mathrm{mm}]$ & 285.582 & 283.512 & 281.441 & 279.371 & 277.300 \\
\hline Basic circle diameter of the driven gear $\left(d_{b 2}\right)[\mathrm{mm}]$ & & & 290.634 & & \\
\hline The $x_{1 h}=-x_{2 h}$ addendum modification [mm] & 0 & 0.1 & 0.2 & 0.3 & 0.4 \\
\hline Transmission ratio $(i)$ & & & 1.5 & & \\
\hline Base profile angle $\left(\alpha_{0}\right)\left[^{\circ}\right]$ & & & 20 & & \\
\hline Tooth trace $\left(\beta_{0}\right)\left[^{\circ}\right]$ & & & 15 & & \\
\hline
\end{tabular}

\subsection{Setting of the meshing, the load and boundary conditions}

The aim of the TCA is the determination and analysis of the mechanical parameters on the contact zone by different loads $[6-13,20]$. Based on this the stresses and deformations could be estimated forward before the real industry circumstances. After the optimized geometry the real production of the elements could be started.

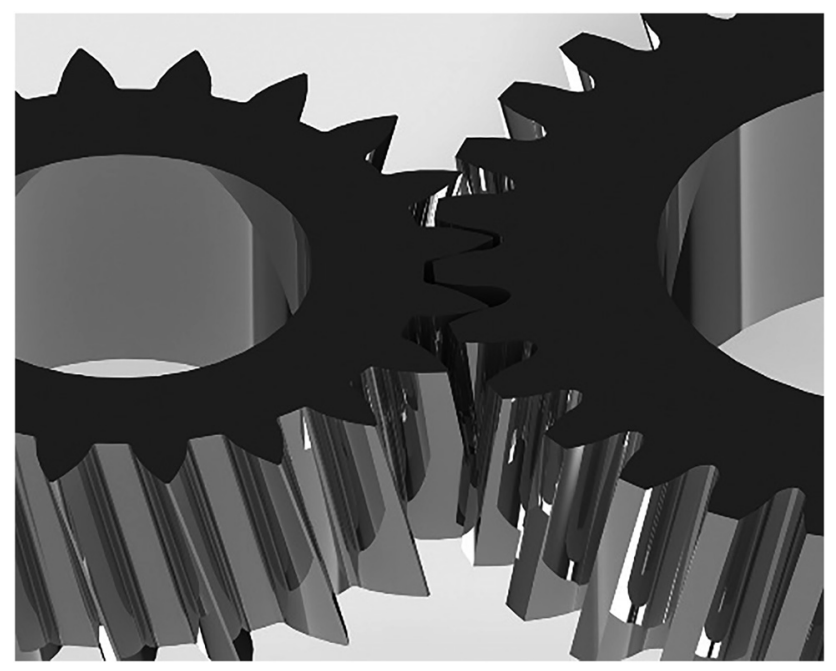

Fig. 2. The CAD models of a designed helical gear pairs $\left(x_{1}=0.4\right)$ by SolidWorks
We needed four coordinate systems for the analysis:

- two coordinate systems are on the middle axes of the elements,

- one coordinate system which has an ' $x$ ' axis which is perpendicular for the tooth surface,

- one coordinate system which has a ' $z$ ' axis which is shown into the axial direction.

We analysed the normal stress and the normal deformation into two directions (normal and axial) [21]. The driven gear was totally fixed. Five degrees of freedom of the pinion were also fixed except the rotation around the axis of rotation. These analyses were done by Ansys FEM software.

Rectangular mesh having $0.6 \mathrm{~mm}$ density was used for the meshing. The rectangular shape was adopted and extruded on the tooth contact zone. Automatic mesh was used on the outside area (Fig. 4).

All of the pinions were loaded by $M=1,200 \mathrm{Nm}$ torque. The established normal stress and deformations were analysed on the contact zone based on this torque. The applied material type was structural steel.

\subsection{Normal stress' distributions}

The received normal stress distributions into the ' $x$ ' normal direction could be seen in Fig. 5 in the case of the pinion and the driven gear.

Based on Fig. 6a the normal stress is continuously being decreased parallel with the increasing of the addendum 

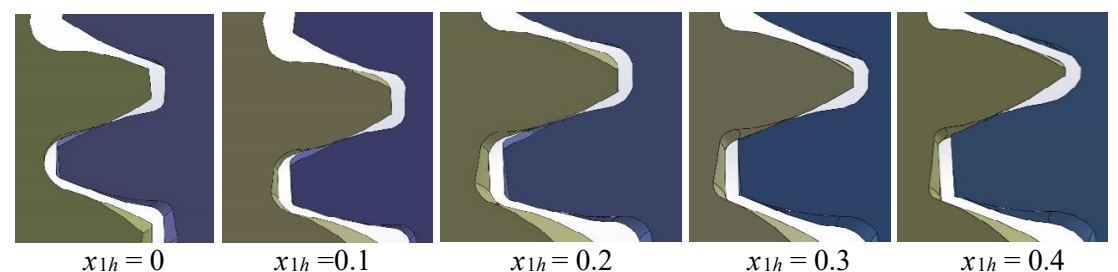

Fig. 3. The profile shapes by the changing of the addendum modification coefficients (left: pinion, right: driven gear)

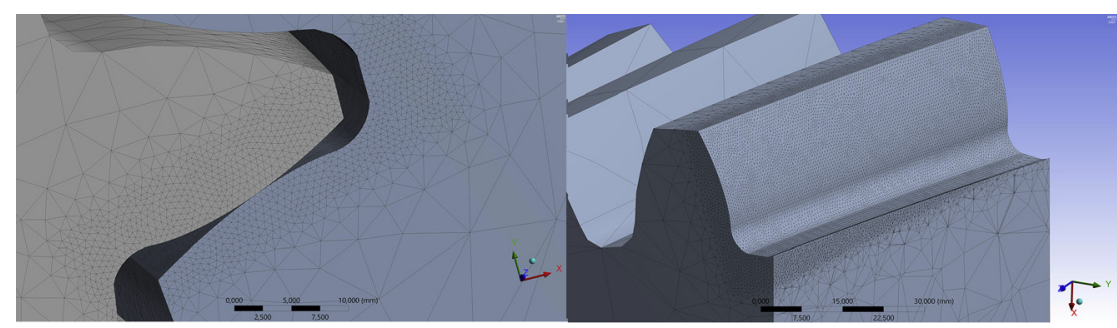

Fig. 4. Adoption of the finite element mesh
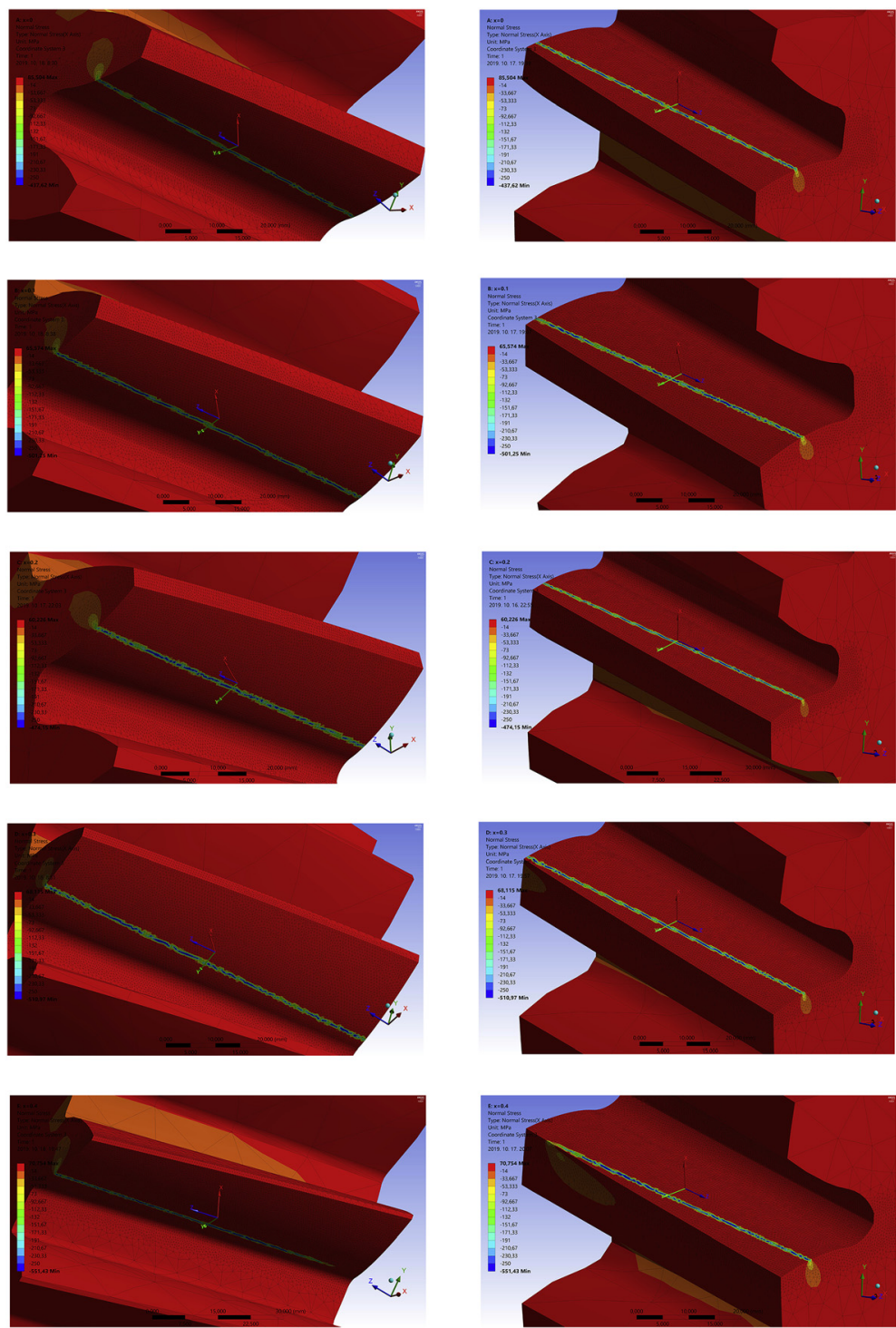

Fig. 5. The ' $x$ ' directional normal stress's distributions 


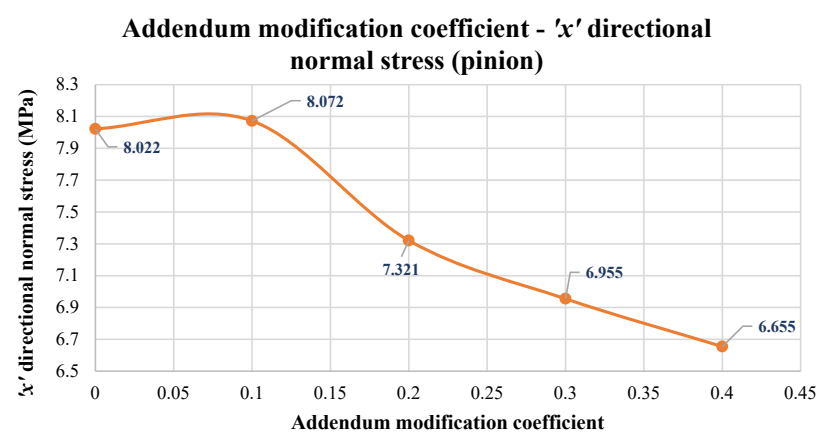

a) pinion

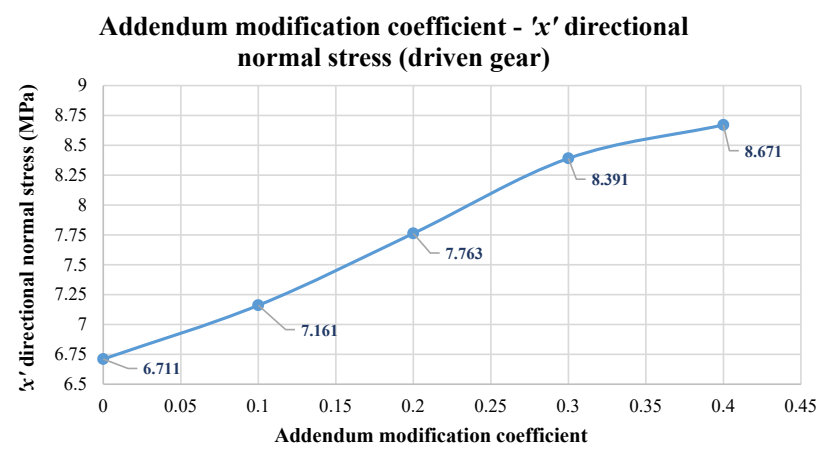

b) driven gear

Fig. 6. The addendum modification - ' $x$ ' directional normal stress diagrams
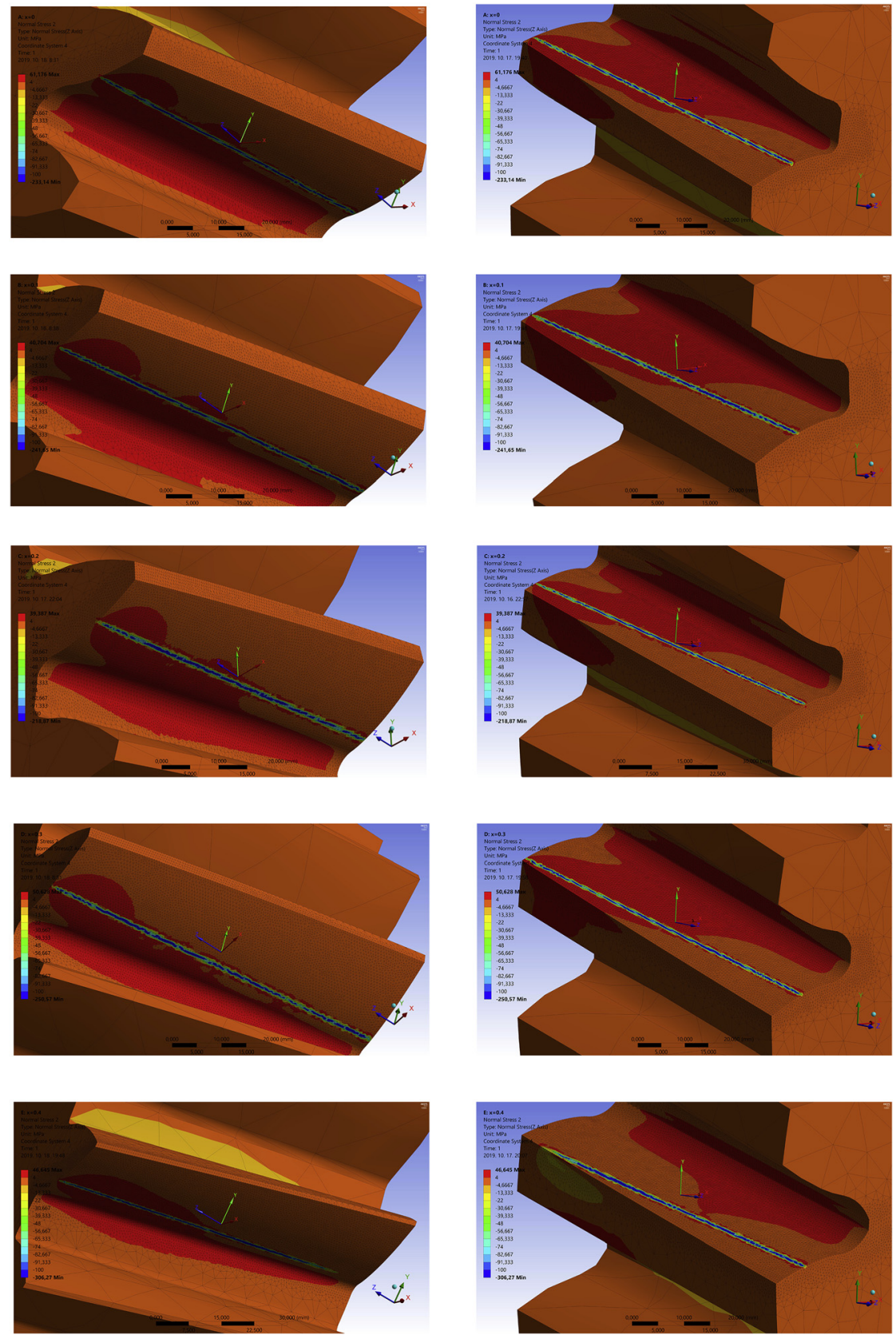

Fig. 7. The ' $z$ ' directional normal stress's distributions 


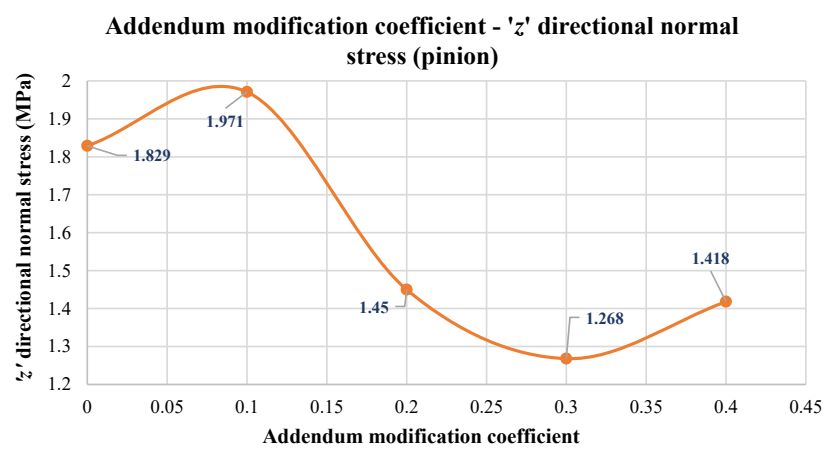

a) pinion

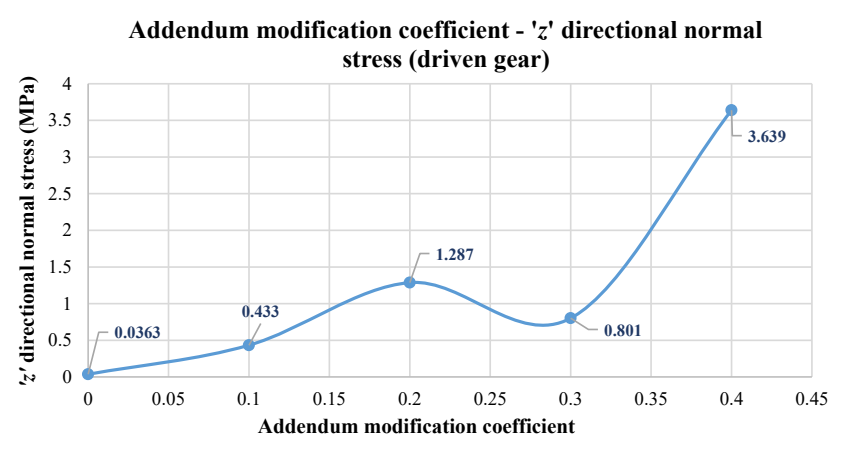

b) driven gear

Fig. 8. The addendum modification coefficient - ' $z$ ' directional normal stress diagrams
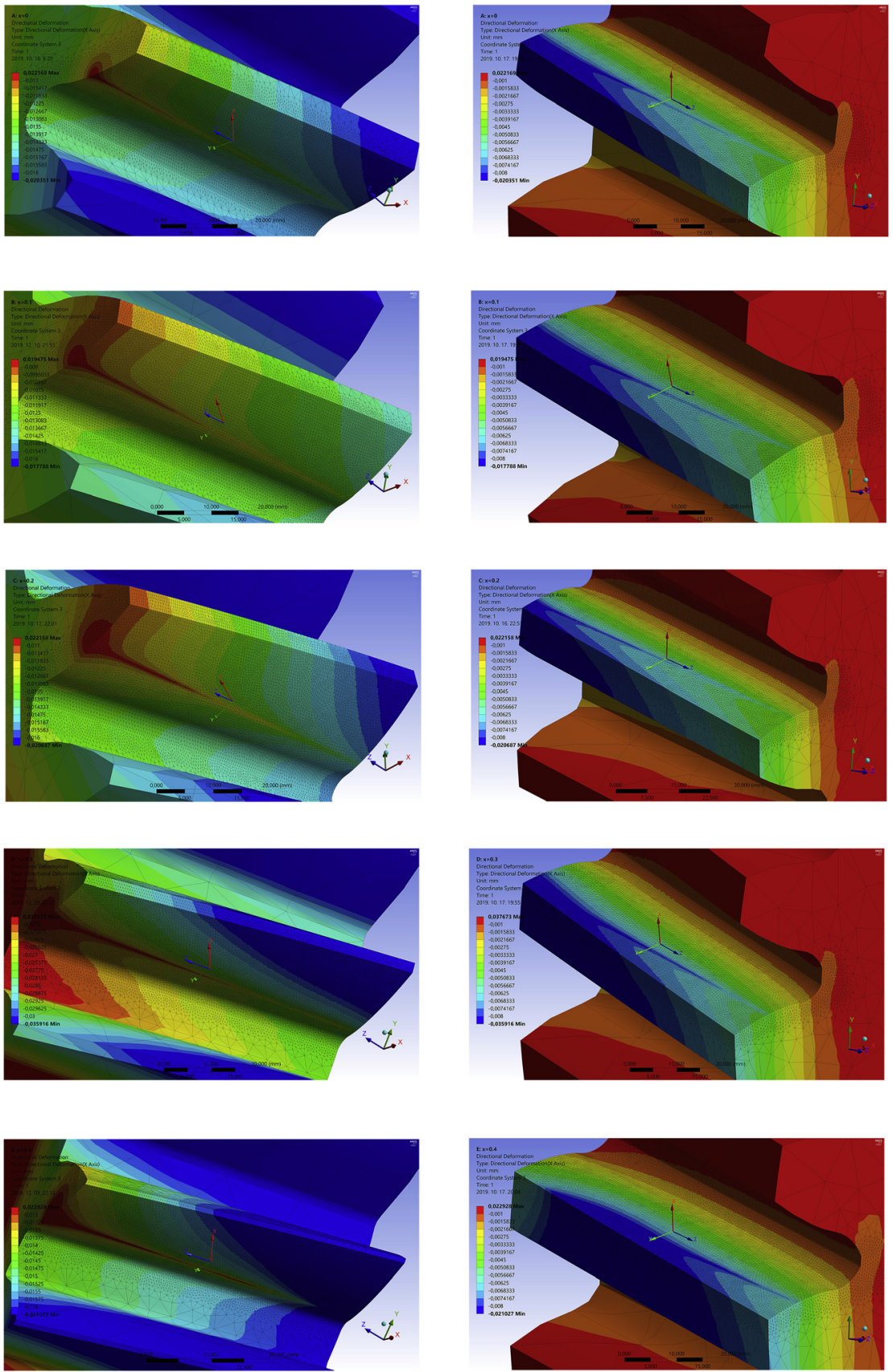

Fig. 9. The ' $x$ ' directional normal deformation's distributions 

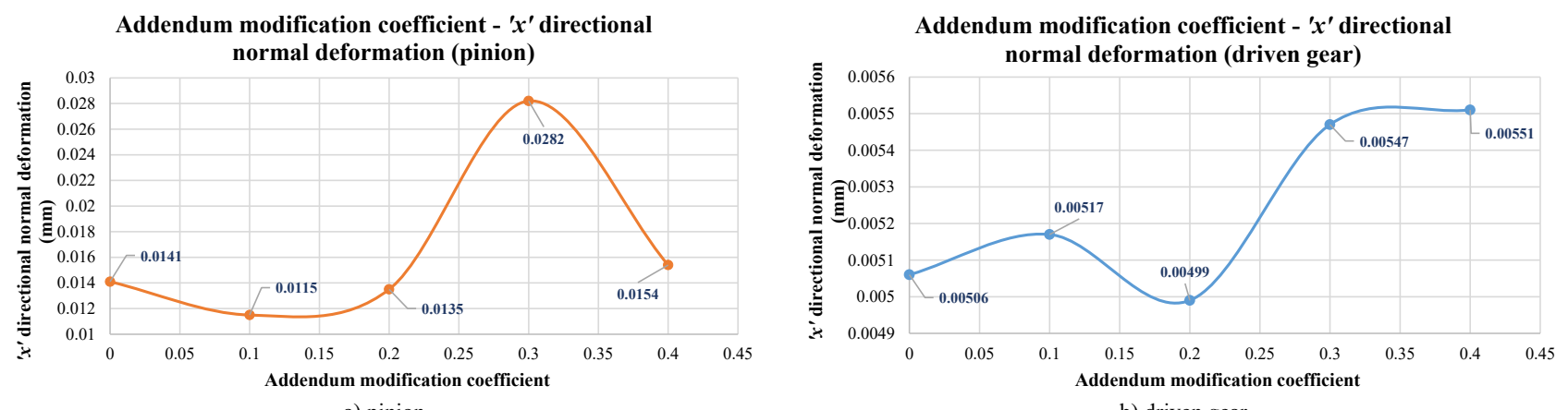

a) pinion

b) driven gear

Fig. 10. The addendum modification coefficient - ' $x$ ' directional normal deformation diagrams
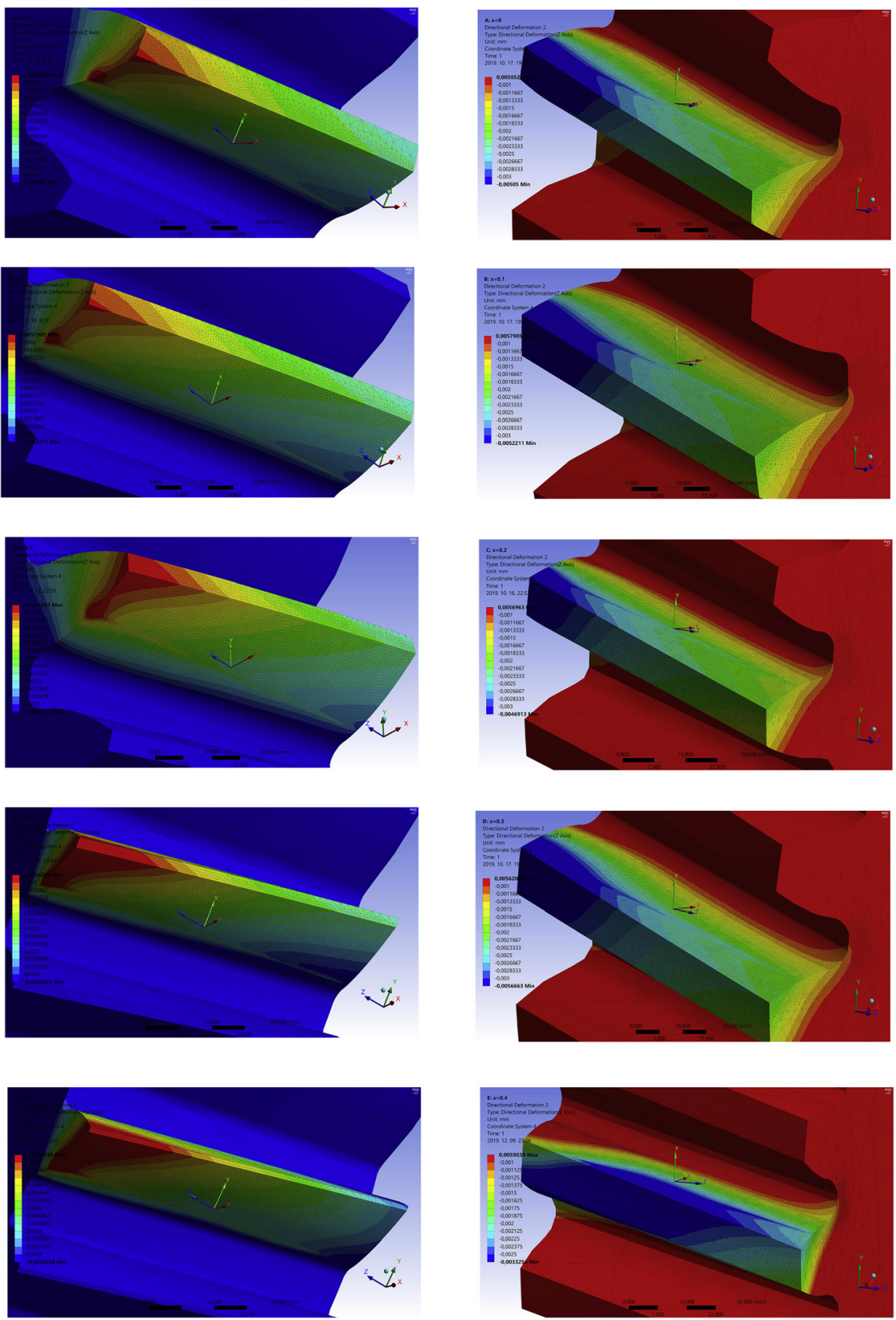

Fig. 11. The ' $z$ ' directional normal deformation's distributions 

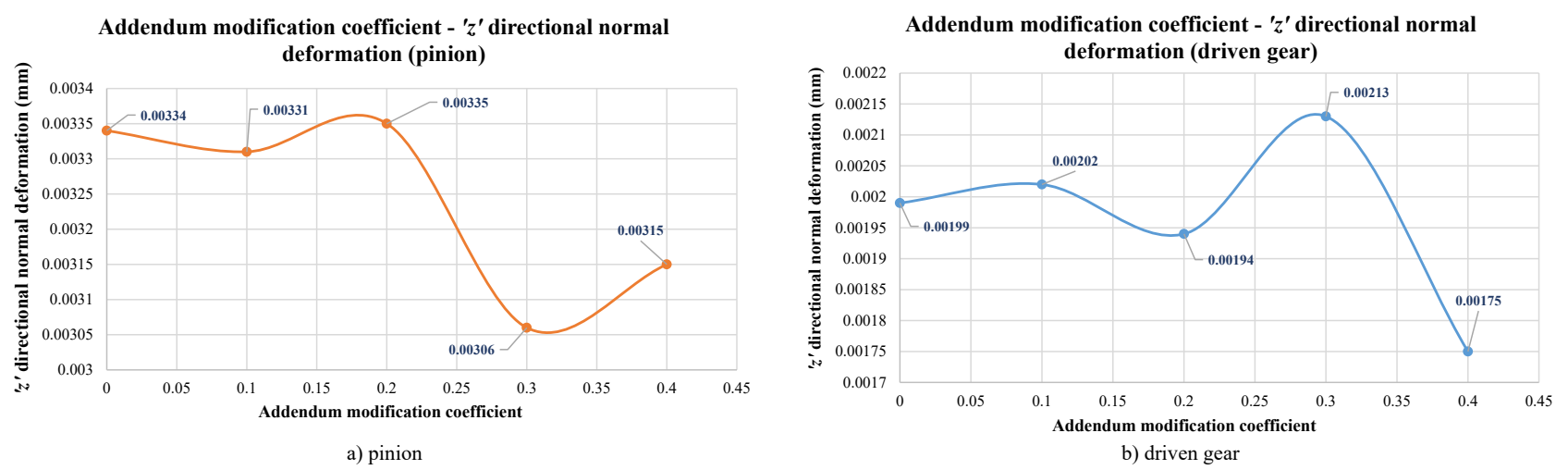

Fig. 12. The addendum modification - ' $z$ ' directional normal deformation diagrams

modification coefficient from $x_{1 h}=0.1$ in the case of the pinion's side. The highest value is at $x_{1 h}=0.1$.

Based on Fig. $6 \mathrm{~b}$ the normal stress is continuously being increased parallel with the increasing of the addendum modification coefficient in the case of the driven gear's side. The highest value is at $x_{1 h}=0$.

The received normal stress distributions into the ' $z$ ' axial direction could be seen in Fig. 7 in the case of the pinion and the driven gear.

Based on Fig. 8a the shape of the diagram is periodical. The highest value is at $x_{1 h}=0.1$. The lowest value is at $x_{1 h}=$ 0.3 .

Based on Fig. $8 \mathrm{~b}$ the shape of the diagram is periodical. The following values are different in dimensions. The highest value is at $x_{1 h}=0.4$. The lowest value is at $x_{1 h}=0$. The highest value is much higher than the lowest value.

\subsection{Normal deformation's distributions}

The received normal deformation's distributions into the ' $x$ ' normal direction could be seen in Fig. 9 in the case of the pinion and the driven gear.

Based on Fig. 10a the lowest value is at $x_{1 h}=0.1$. The highest value is $x_{1 h}=0.3$. The changing of the shape of the diagram is periodical.

Based on Fig. 10b the lowest value is at $x_{1 h}=0.2$. The highest value is $x_{1 h}=0.4$. The changing of the shape of the diagram is periodical. The deformation results are much lower than in the case of the pinion.

The received normal deformation distributions into the ' $z$ ' axial direction could be seen in Fig. 11 in the case of the pinion and the driven gear.

Based on Fig. 12a the highest value is at $x_{1 h}=0.2$. The lowest value is at $x_{1 h}=0.3$. In spite of this, the highest value is at $x_{1 h}=0.3$ in the case of the driven gear. The lowest value is at $x_{1 h}=0.4$. The shapes of the diagrams are periodical.

\section{CONCLUSION}

We have created a computer program with which the geometric parameters and the involute profiles of the helical gears could be determined considering the references' recommendations. After that the CAD models of the elements and the correct assembly could be done by SolidWorks software. Five different types of helical gear having modified teeth were designed by different addendum modification coefficients. All of the other input parameters were the same.

The aim of the research is the analysis of the received mechanical parameters (normal stress and deformation) based on the changing of the addendum modification coefficient by the help of TCA. This analysis is important before the real gear production because the mechanical parameters on the tooth contact zone could be further determined. Considering the results, the gear geometry could be optimized from the aspect of a selected mechanical condition.

We analysed the normal stresses and deformations into ' $x$ ' normal and ' $z$ ' axial directions. We did the analysis for all of the designed gear pairs. We have created diagrams in the function of the given mechanical parameter and the changing of the addendum modification coefficient. Based on the received shapes we evaluated the results and determined the conclusions.

\section{ACKNOWLEDGEMENT}

Supported by the ÚNKP-19-4 New National Excellence Program of the Ministry for Innovation and Tech-

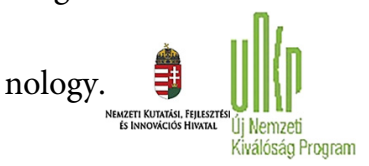

\section{REFERENCES}

[1] D. W. Dudley, Gear Handbook, New York-Toronto-London, MC Graw Hill Book Co., 1962.

[2] F. L. Litvin and A. Fuentes, Gear Geometry and Applied Theory, Cambridge University Press, 2004, ISBN 9780521815178.

[3] V. Rohonyi, Fogaskerékhajtások, Budapest, Müszaki Könyvkiadó, 1980.

[4] Z. Terplán, Gépelemek IV., Tankönyvkiadó, Budapest, Kézirat, 1975 , p. 220.

[5] S. P. Radzevich, Dudley's Handbook of Practical Gear Design and Manufacture, 3rd ed., CRC Press, 2016, p. 656, ISBN 9781498753104. 
[6] Y. Peng, N. Zhao, P. Qui, M. Zhang, W. Li, and R. Zhuo, An Efficient Model of Load Distribution for Helical Gears With Modification and Misalignment, Mechanism and Machine Theory, Elsevier, 2018, pp. 151-68, https://doi.org/10.1016/j. mechmachtheory.2017.10.019.

[7] J. D. M. Marafona, P. M. T. Marques, and R. C. Martins, Towards Constant Mesh Stiffness Helical Gears: The Influence of Integer Overlap Ratios, Mechanism and Machine Theory, Elsevier, 2019, pp. 141-61, https://doi.org/10.1016/j.mechmachtheory.2019.02.008.

[8] J. Zhan, and M. Fard, Effects of Helix Angle, Mechanical Errors, and Coefficient of Friction on The Time-Varying Tooth-Root Stress of Helical Gears, Measurement, Elsevier, 2018, pp. 135-46, https:// doi.org/10.1016/j.measurement.2018.01.021.

[9] Y. Huangfu, K. Chen, H. Ma, L. Che, Z. Li, and B. Wen, Deformation and Meshing Stiffness Analysis of Cracked Helical Gear Pairs, Engineering Failure Analysis, Elsevier, 2019, pp. 36-46, https://doi.org/10.1016/j.engfailanal.2018.08.028.

[10] R. G. Costin and S. Cananau, "Contact analysis of helical gears by using finite element method," Proceedings of 2018 International Conference on Hydraulics and Pneumatics - HERVEX, ISSN 1454-8003, Romania, 2018, pp. 172-6.

[11] M. G. Khosroshahi and A. M. Fattahi, "Three dimensional stress analysis of a helical gear drive with finite element method," Mechanika, 2017, vol. 23, pp. 630-8., ISSN 1392-1207, http://dx. doi.Org/10.5755/j01.mech.23.5.14884.

[12] Y. Wang, Y. Liu, W. Tang, and P. Liu, "Parametric finite element modeling and tooth contact analysis of spur and helical gears including profile and lead modifications", Eng. Comput., vol. 34, no. 8, 2017,ISSN 0264-4401, https://doi.org/10.1108/EC-06-2016-0203.

[13] A. Dimic, Z. Miskovic, R. Mitrovic, M. Ristivojevic, Z, Stamenic, J. Danko, J. Bucha, and T. Mileshich, "The influence of material on the operational characteristics of spur gears manufactured by the 3D printing technology," Strojnícky časopis - J. Mech. Eng.,
Slovakia, vol. 86, no.3, 2018, pp. 261-70, https://doi.org/10.2478/ scjme-2018-0039.

[14] T. Nieszporek, P. Boral, and R. Gołębski, An Analysis of Gearing, The $4^{\text {th }}$ International Conference on Computing and Solutions in Manufacturing Engineering 2016 - CoSME'16, vol. 94, 2016, https://doi.org/10.1051/matecconf/20179407006.

[15] F. L. Litvin, A. Fuentes, I. Gonzalez-Perez, R. Carvenali, K. Kawasaki, and R. F. Handschuh, "Modified Involute Helical Gears: Computerized Design, Simulation of Meshing and Stress Analysis", Computer Methods in Applied Mechanics and Engineering, Elsevier, 2003, pp. 3619-55, https://doi:10.1016/S0045-7825(03) 00367-0.

[16] F. L. Litvin, I. Gonzalez-Perez, A. Fuentes, D. Vecchiato, B. D. Hansen, and D. Binney, "Design, Generation and Stress Analysis of Face-Gear Drive with Helical Pinion", Computer Methods in Applied Mechanics and Engineering, Elsevier, 2005, pp. 3870-901, https://doi:10.1016/j.cma.2004.09.006.

[17] R. Gołębski and A. Szarek, "Diagnosis of the operational gear wheel wear," Technical Gazette, vol. 26, no. 3, pp. 658-61, 2019, ISSN 1848-6339, https://doi.org/10.17559/TV-20180321171428.

[18] R. Gołębski and Z. Ivandic, "Analysis of modification of spur gear profile,” Tehnički vjesnik vol. 25, no. 2, pp. 643-8, 2018, ISSN 1848-6339, https://doi.org/10.17559/TV-20171018100732.

[19] T. Nieszporek, R. Gołębski, and L. Soos, "Analiza točnosti ozubljenja pužnog kola," Tehnički vjesnik, vol. 28, no. 4, pp. 993-1000, 2017, ISSN 1848-6339, https://doi.org/10.17559/TV20160422094400.

[20] S. Bodzás, "Tooth contact analysis of x-zero helical gears by the modification of the tooth trace," Int. J. Automotive Sci. Technol., eISSN 2587-0963, 2019.

[21] S. Moaveni, Finite Element Analysis. Theory and Application with ANSYS, Pearson Education Limited, 2015, ISBN 10: 0-273-774301, p. 928. 